\title{
Aspects of developmental and mortality rates in Calanus finmarchicus related to equiproportional development
}

\author{
Kurt S. Tande \\ Department of Aquatic Biology, Institute of Biology and Geology, University of Tromse, PO Box 3085 Guleng, N-9001 Tromsø, \\ Norway
}

\begin{abstract}
The marine copepod Calanus finmarchicus from coastal areas of northern Norway was cultivated at 3 temperatures from egg to adult in the laboratory. Growth and survival of copepodite stages were markedly affected by the temperature regime. If populations of copepodite Stage I experience a sharp decrease in temperature, mortality rate is increased. On this basis the hypothesis is formulated that during the main annual growth period of $C$. finmarchicus in arctic-boreal areas not only is this species sensitive to a temperature decrease, but also a certain temperature increase is a prerequisite to successful growth from copepodite Stage I to copepodite Stage IV and V. The ecological implications of this hypothesis are discussed. Temperature-dependent mortality rates in certain growth periods of $C$. finmarchicus are also related to the postulated rule of equiproportional development in marine copepods.
\end{abstract}

\section{INTRODUCTION}

Environmental conditions such as temperature and food supply are considered to be the most important factors determining growth of herbivorous marine copepods. Investigations have been carried out on the way in which developmental rate and adult size, 2 important aspects of growth, are governed by the dynamic interactions between food supply and temperature (see Paffenhöfer \& Harris 1979 for review). Experimental research, mainly conducted on temperate and warm water species, has revealed some general trends in these aspects of growth of marine planktonic copepods (Vidal 1980a, b, c, d).

Rules describing the development of marine copepods have been proposed, including the rule of equiproportional development (Corkett 1984, Corkett \& al. 1986, McLaren 1986), which states that each developmental stage occupies the same proportion of time at any constant temperature if food is overabundant. This rule was first proposed for various species of small copepods of the genera Acartia and Pseudocalanus (Corkett \& McLaren 1970, Miller \& al. 1977, Corkett \& McLaren 1978). McLaren (1978) has even suggested that the rule is valid for virtually all neritic copepods, but this has been criticized by others (Uye 1980, Thompson 1982, Landry 1983).

In laboratory experiments, the influence of temperature on rates of growth and development has received considerable attention, and McLaren (1978) has suggested that temperature may be the only variable affecting the development of marine copepods in nature. Temperature-dependent developmental rates have been investigated by conducting growth experiments at fixed temperature levels throughout the whole life cycle of the species under study (see Paffenhöfer \& Harris 1979). In natural environments, however, seasonal variations in sea temperature may expose copepod species to different temperature levels throughout their life cycle. The possible significance of regular temperature changes on different growth periods of copepods has been little studied.

A number of studies have examined growth and developmental rates in arctic-boreal planktonic copepods of the genus Calanus (Matthews 1966, Conover 1967, Runge et al. 1985, Corkett et al. 1986). Calanus finmarchicus is the dominant member of the zooplankton community in coastal areas of northern Norway and in the Atlantic region of the Barents Sea (Tande 1982, Tande et al. 1985) and spends the greater 
part of its most intensive growth period from April to June in temperatures ranging from ca 0 to $6^{\circ} \mathrm{C}$. In coastal areas of northern Norway, the onset of the temperature increase in surface waters coincides with the period during which the majority of the $C$. finmarchicus stock passes through the copepodite stages, whereas in different regions of the Barents Sea a quite variable temperature regime is found during this period. The purpose of the present experiments was to evaluate possible effects of different temperature regimes upon mortality and developmental rates in nauplii and copepodite stages of $C$. finmarchicus from ca $70^{\circ} \mathrm{N}$ in coastal areas of northern Norway. The data presented were obtained from cultivation experiments conducted in the laboratory.

\section{MATERIALS AND METHODS}

Experiments on developmental and mortality rates of nauplii Calanus finmarchicus were carried out during spring 1980, and experiments on copepodite stages during spring 1981.

Calanus finmarchicus were collected in April, either at Svartnes in Balsfjorden $\left(69^{\circ} 21^{\prime} \mathrm{N}, 19^{\circ} 08^{\prime} \mathrm{E}\right)$ or Grotsund north of Tromsø (ca $69^{\circ} 46^{\prime} \mathrm{N}, 19^{\circ} 08^{\prime} \mathrm{E}$ ). Gravid females were collected with a WP-2 plankton net $(0.5$ mouth diameter, $500 \mu \mathrm{m}$ mesh size) hauled obliquely from ca $180 \mathrm{~m}$ to the surface. The contents of the cod ends were transferred to containers (ca 50 l) previously filled with seawater from the surface. Adult females were sorted from the freshly collected samples and placed in $1 \mathrm{l}$ beakers filled with filtered seawater (ca 100 ind. $\mathrm{I}^{-1}$ ). The diatoms Chaetoceros septentrionalis Oustrup (ca $140 \mathrm{\mu m}^{3}$ in volume), C. decipiens Cleve (ca $4200 \mu^{3}$ ) and Thalasiossira hyalina (ca $17000 \mu \mathrm{m}^{3}$ ) were added as food.

Cultivation of nauplii. Each experiment was started with eggs spawned over a $24 \mathrm{~h}$ period. The eggs were transferred by pipette into beakers filled with $4000 \mathrm{ml}$ GFC-filtered seawater (ca 150 eggs $\mathrm{I}^{-1}$ ), The beakers were placed in walk-in cold rooms at $0.5,2$ and $5^{\circ} \mathrm{C}$. Nauplii Stages I and II are considered not to feed (Marshall \& Orr 1972), so phytoplankton concentrations were increased gradually from Days 5 to 14 after inoculation. At the end of this period food concentrations of $50,100,300$ and $700 \mu \mathrm{g} \mathrm{Cl}^{-1}$ had been established by adding diatoms, either Thalasiossira hyalina or Chaetoceros septentrionalis, to one beaker at each temperature level, respectively. No special means were used to keep the algae in suspension. Most of the settled algae were removed each third day and the water removed with the algae was replaced with filtered seawater. Food concentrations were monitored occasionally using a Model ZB Coulter Counter after water replacement, and were re-adjusted to 50, 100 , 300 and $700 \mu \mathrm{g} \mathrm{C}{ }^{-1}$. During the experiments food concentrations in the beakers were never estimated to be below 45 or $18 \mu \mathrm{g} \mathrm{C}^{-1}$ in beakers containing $C$. septentrionalis or $T$. hyalina, respectively. Every $5 \mathrm{~d}$ nauplii were removed from the cultures for identification of stage composition. Approximately 20 to 50 individuals were sampled each time using a full pipette coupled to a vacuum pump. When copepodite Stage I were recorded in the beakers all the remaining nauplii were filtered out from the cultures, and stored in a freezer at $-15^{\circ} \mathrm{C}$, for later identification.

Cultivation of copepodite stages. Stage I copepodites were raised from nauplii at $2{ }^{\circ} \mathrm{C}$ in the laboratory. To rear copepodite stages, $300 \mathrm{CI}$ copepodites were transferred to each of several glass beakers containing $3 \mathrm{l}$ of filtered seawater from the naupliar cultures diluted with $7 \mathrm{l}$ of freshly filtered seawater. The beakers were placed in temperature-regulated water baths at $0.5,3$ and $5^{\circ} \mathrm{C}$ for the duration of the experiments. Continuous mixing with plunger-jar stirrers kept sedimentation to the algae cells at low levels (Frost 1972).

Equal amounts (by carbon) of the diatoms Thalasiossira hyalina and Chaetoceros septentrionalis were used as food. In each temperature series the total

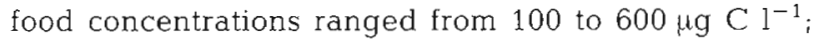
further details of the experimental set up are given in Table 1. Food concentrations were measured once a day with a Model ZB Coulter Counter, and the cells

Table 1. Calanus finmarchicus. Mean food concentrations in cultures at various temperatures during the copepodite growth period

\begin{tabular}{cccc}
$\begin{array}{c}\text { Experiment } \\
\text { no. }\end{array}$ & $\begin{array}{c}\text { Temperature } \\
\left({ }^{\circ} \mathrm{C}\right)\end{array}$ & $\begin{array}{c}\text { Concentration } \\
\left(\text { (ug } \mathrm{C} l^{-1}\right)\end{array}$ & $\begin{array}{c}\text { Confidence } \\
\text { limits }(95 \%)\end{array}$ \\
\hline 1 & 0.5 & 125 & \pm 26.3 \\
2 & & 152 & \pm 50.6 \\
3 & & 176 & \pm 19.1 \\
4 & & 257 & \pm 48.8 \\
5 & & 298 & \pm 62.5 \\
6 & & 259 & \pm 54.5 \\
7 & & 344 & \pm 48.7 \\
8 & & 430 & \pm 89.4 \\
11 & 3 & 81 & \pm 9.3 \\
12 & & 157 & \pm 11.0 \\
13 & & 270 & \pm 38.3 \\
14 & & 380 & \pm 32.5 \\
15 & & 594 & \pm 53.0 \\
21 & 6 & 166 & \pm 14.9 \\
22 & & 168 & \pm 10.4 \\
23 & & 313 & \pm 20.2 \\
24 & & 369 & \pm 22.1 \\
25 & & 454 & \pm 50.0 \\
26 & & 549 & \pm 15.6
\end{tabular}


Table 2. Temperature at initial sampling dates in April and temperature increase at 3 selected depth strata from selected fjords in the area around Tromsø, northern Norway, during the recruitment period of Calanus finmarchicus

\begin{tabular}{|c|c|c|c|c|}
\hline \multirow[t]{2}{*}{ Locality and year } & \multirow{2}{*}{$\begin{array}{l}\text { Initial temperature } \\
\qquad\left({ }^{\circ} \mathrm{C}\right)^{\mathrm{a}}\end{array}$} & \multicolumn{3}{|c|}{ Temperature increase $\left(\mathrm{C}^{\circ}\right)$} \\
\hline & & $0-19 \mathrm{~m}$ & $20-49 \mathrm{~m}$ & $50-100 \mathrm{~m}$ \\
\hline Balsfjorden, $1977^{\circ}$ & $1.21-1.72$ & 4.72 & 2.44 & 0.89 \\
\hline Ullsfjorden, $1981^{c}$ & $1.40-2.80$ & 3.02 & 2.79 & 2.42 \\
\hline Ullsfjorden, $1982^{d}$ & $2.71-4.22$ & 3.13 & 2.53 & 1.51 \\
\hline
\end{tabular}

removed by grazing or sedimentation were replaced with an equal amount of fresh phytoplankton cultures.

Samples of copepodites were removed from each experimental container at intervals of 5 to $10 \mathrm{~d}$. The copepods were sampled using a $5 \mathrm{~cm}$ diameter plastic tube with a Nitex screen base. Samples were filtered through a plankton gauze $(50 \mu \mathrm{m}$ mesh size) rinsed with distilled water, and stored in a freezer at $-15^{\circ} \mathrm{C}$ for later identification.

Estimation of mortality rate. The various experiments were started with a known initial number each of eggs and copepodites of Stage I. The total number of individuals sampled from the different populations was also recorded. On the basis of this an instantaneous mortality' $(m)$ was calculated as:

$$
m=\left(\ln N_{t-1}-\ln N_{1}\right) / t
$$

where $N_{t-1}=$ number of eggs or copepodite Stagc I at start of each series; $N_{1}=$ total number of living individuals removed from the container during and at the end of the experimental period; $t=$ duration of each experiment (d). Calculating mortality rates in this way has obvious limitations. Since the populations of copepodites were sampled more frequently than the naupliar populations and total number of individuals sampled differed for the different temperature regimes, this would be expected to affect the estimates of $m$. In performing the calculations it is also assumed that individuals removed at the different sampling times would all have survived. This substantially underestimates total mortality of naulii and copepodites. However, since the purpose of the work was to indicate relative differences between temperature regimes, the estimations of $m$, although only approximate, are adequate for present purposes.

Natural temperature and food conditions during recruitment. Calanus finmarchicus in coastal and fjord areas north of Lofoten have an annual reproduction and recruitment period from April until mid June (Tande 1982). Spawning in April takes place at minimum temperatures, which vary from year to year and between different localities (Table 2). The inten- sive growth of C. finmarchicus during May and June coincides with the yearly build up of a thermocline, most pronounced in surface waters (Fig. 1). Information

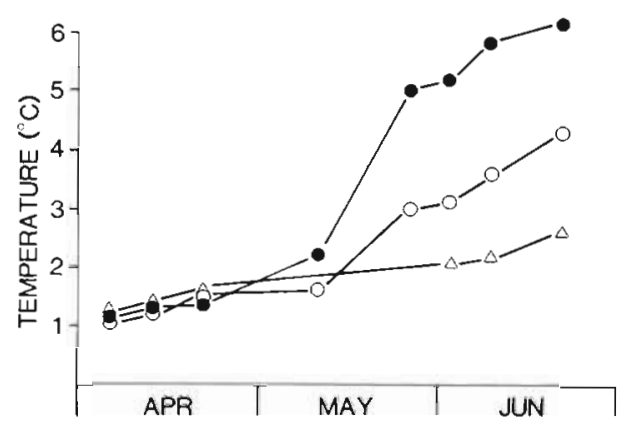

Fig. 1 Temperatures in different depth strata from April to June 1977 at Svartnes, Balsfjorden, northern Norway. $(\bullet-19$

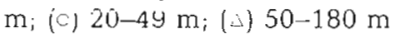

about food availability in these waters indicates particulate organic carbon content $>\mathrm{ca} 350 \mu \mathrm{g} \mathrm{C} \mathrm{l^{-1 }}$ and cell concentrations in general $>3 \times 10^{5}$ cells $\mathrm{l}^{-1}$ during the same period (Table 3 )

Table 3. Particulate organic carbon $\left(\mu \mathrm{g} \mathrm{Cl} \mathrm{Cl}^{-1}\right)$ and cell concentrations (counts $1^{-1} \times 10^{5}$ ) at Svartnes, Balsfjorden. Concentrations are computed by graphic integration over 0 to $16 \mathrm{~m}$ (from 7 depths). Data from Eilertsen \& Taasen (1984)

\begin{tabular}{|rcc|}
\hline $\begin{array}{l}\text { Date of } \\
\text { sampling }\end{array}$ & $\begin{array}{c}\text { Particulate organic } \\
\text { carbon (ug }\left(\mathrm{l}^{-1}\right)\end{array}$ & $\begin{array}{c}\text { Cell concentration } \\
\left.\text { (counts } 1^{-1} \times 10^{5}\right)\end{array}$ \\
\hline April 5 & 346 & 5.50 \\
14 & 451 & 10.19 \\
21 & 639 & 12.60 \\
29 & 977 & 7.10 \\
May 3 & 526 & 9.67 \\
10 & 488 & 3.01 \\
26 & 751 & 4.01 \\
June 8 & 376 & 0.38 \\
22 & 713 & 3.95 \\
\hline
\end{tabular}




\section{RESULTS}

\section{Developmental time}

Estimates of developmental time for the naupliar growth period and the various copepodite stages of Calanus finmarchicus from coastal areas of northern Norway are given in Figs. 2 and 3. Mean developmental time for the naupliar period varied inversely with experimental temperature and decreased from $42 \mathrm{~d}$ at $0.5^{\circ} \mathrm{C}$ to 27 d at $5^{\circ} \mathrm{C}$. The mean developmental times

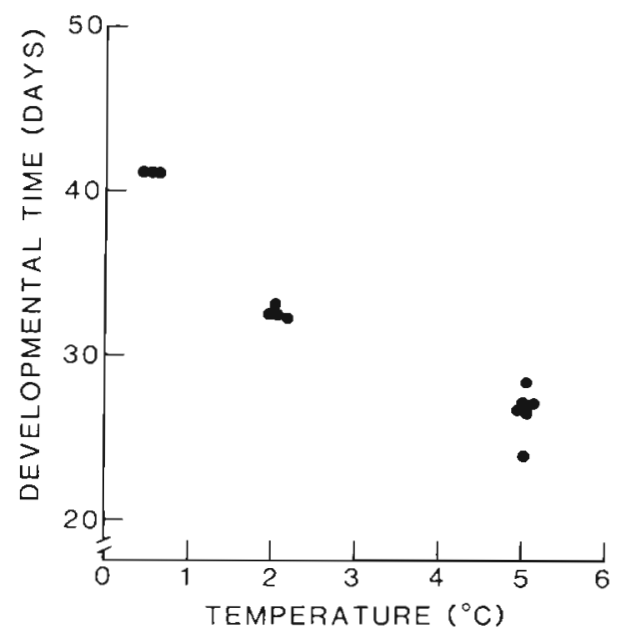

Fig. 2. Calanus finmarchicus. Developmental time for the nauplii period (from hatching to the first appearance of $\mathrm{CI}$ ) cultivated at 3 different temperatures

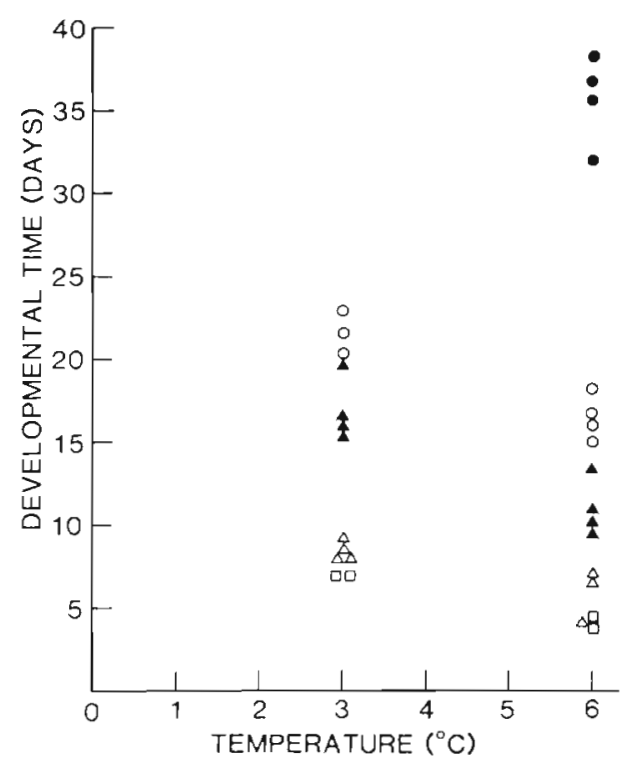

Fig. 3. Calanus finmarchicus. Development time for copepodite stages cultivated at different temperatures. $(\bullet) \mathrm{CI}_{i}(\iota) \mathrm{CII}$ (^) CIII (o) CIV; (-) CV for copepodite Stages I to $\mathrm{V}$ were estimated for 3 and $6{ }^{\circ} \mathrm{C}$ (Fig. 3). At $0.5^{\circ} \mathrm{C}$ no estimate was obtained due to heavy mortality. The time taken to develop from $\mathrm{CI}$ to CII increased from $6 \mathrm{~d}$ at $6^{\circ} \mathrm{C}$ to $8 \mathrm{~d}$ at $3^{\circ} \mathrm{C}$, whereas developmental time from $\mathrm{CI}$ to CIII increased from 11 to $17 \mathrm{~d}$. Developmental times to CIV were 17 and $22 \mathrm{~d}$ at 6 and $3{ }^{\circ} \mathrm{C}$, respectively. At $6{ }^{\circ} \mathrm{C}, \mathrm{C}$. finmarchicus needed $36 \mathrm{~d}$ to develop from $\mathrm{CI}$ to $\mathrm{CV}$.

\section{Equiproportional development}

The rule of equiproportional development that has been suggested for some calanoid copepods states that each developmental stage occupies the same proportionate amount of time relative to other stages at any constant temperature (Corkett 1984, McLaren 1986). The relative rate of development of nauplii (i.e. from hatching to $\mathrm{CI}$ ) as a function of temperature has been calculated for Calanus finmarchicus from coastal areas of northern Norway (Fig. 4). The data were log-

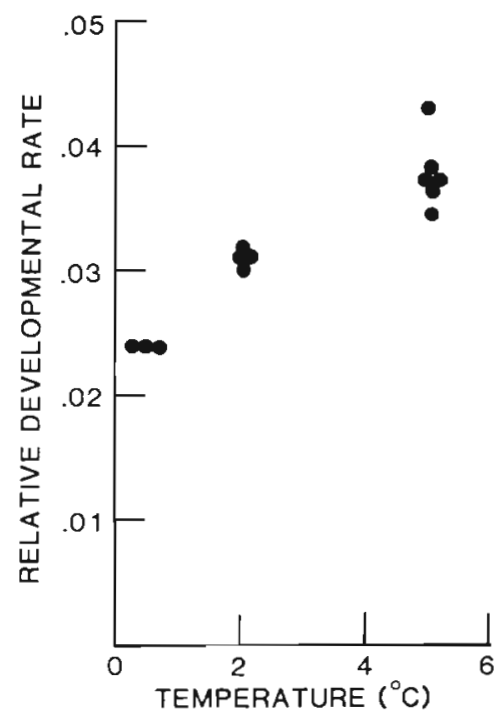

Fig. 4. Calanus finmarchicus. Relative developmental rates $\left(\mathrm{d}^{-1}\right)$ for the nauplii growth period (from hatching to first appearance of $\mathrm{Cl}$ ) as a function of temperature

transformed and the relationship between relative rate of development and temperature was described by log $y=-1.54+0.159 \log x\left(r^{2}=0.924\right)$. The relative rates of nauplii development at 3 and $6{ }^{\circ} \mathrm{C}$ calculated from this function were then combined with the observed mean developmental time (in d) of copepodite stages given in Fig. 3. Although the present calculations are based upon a simplified logarithmic transformation, and not the Belehradek function (McLaren et al. 1969, Corkett 1972), this is considered to give a proper basis for estimation of the temperature-dependent relative 
developmental rate among nauplii of C. finmarchicus from coastal areas of northern Norway.

The results of the calculation are shown in Table 4 along with data presented by Thompson (1982) and McLaren \& Corkett (1986). If Calanus finmarchicus followed the rule of equiproportional development one should expect the same relative developmental rates at 3 and $6{ }^{\circ} \mathrm{C}$. The relative time to reach the various copepodite stages of $C$. finmarchicus from northern Norway appears consistently higher at $3^{\circ} \mathrm{C}$ than at $6{ }^{\circ} \mathrm{C}$. The relative developmental times from hatching to CIII and CIV, respectively, are in general greater for C. finmarchicus from the Scotian Shelf (Corkett 1984) than those gained in experiments of the same species at $6{ }^{\circ} \mathrm{C}$ from Balsfjorden, northern Norway. On the other hand, CV from Balsfjorden has a greater relative developmental time than that from the Shelf area in Nova Scotia. The relative developmental time for CII and CIII C. finmarchicus s. 1 . from the North Sea (Thompson 1982) is in accordance with those from northern Norway growing at $3{ }^{\circ} \mathrm{C}$, but $\mathrm{CIV}$ and $\mathrm{CV}$ seem not to fit into any of the developmental patterns seen in Table 4.

\section{Mortality rates}

The mortality rates of nauplii of Calanus finmarchicus from coastal areas of northern Norway cultivated at $5{ }^{\circ} \mathrm{C}$ were significantly higher than at 0.5 and $2{ }^{\circ} \mathrm{C}$ (Fig. 5). A Mann-Whitney U-test (Sokal \& Rohlf 1981) showed no significant differences $(p=0.068)$ between mortality rates at 0.5 and $2{ }^{\circ} \mathrm{C}$. Opposite trends in temperature-dependent mortality rates of $C$. finmarchicus copepodite stages can be seen in Fig. 6 , where the mortality is significantly higher at $0.5^{\circ} \mathrm{C}$ than at 3 and $6{ }^{\circ} \mathrm{C}$. Comparing the results from the 2 highest temperatures, a larger variation in mortality rates is found between populations cultivated at $3^{\circ} \mathrm{C}$, but a Mann Whitney $U$-test showed that these observations are not significantly different $(p=0.14)$ from mortality rates at $6^{\circ} \mathrm{C}$.

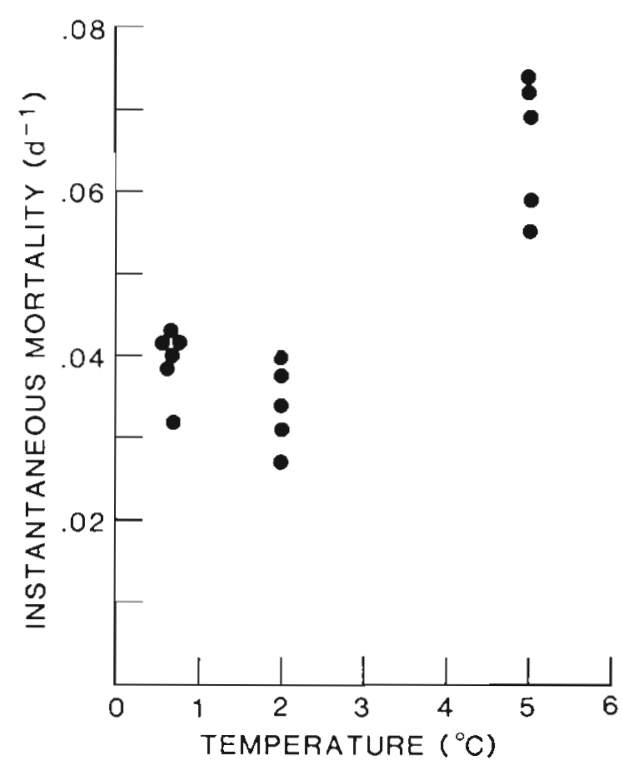

Fig. 5. Calanus finmarchicus. Instantaneous mortality rates for nauplii cultivated at different temperatures

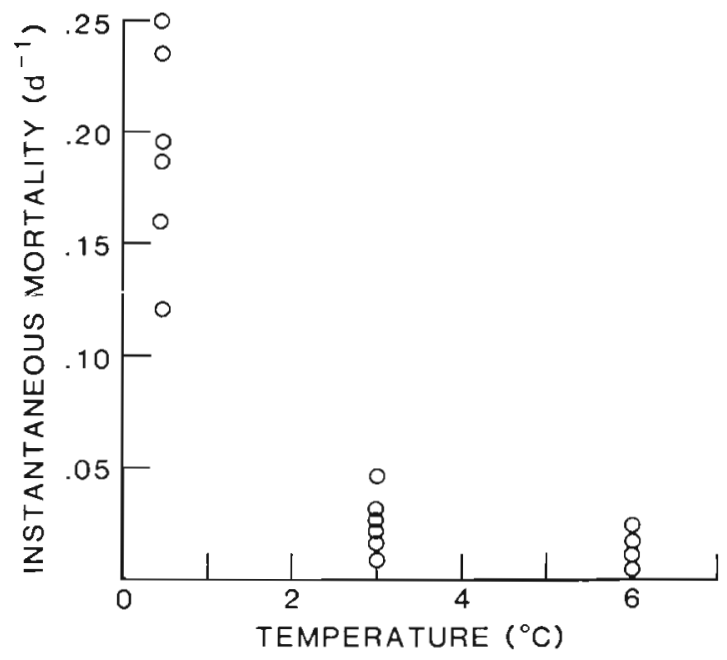

Fig. 6. Calanus finmarchicus. Instantaneous mortality rates for copepodites cultivated at different temperatures

Table 4. Calanus finmarchicus. Relative time to reach various stages of development for cultivated copepods at 2 different temperatures assuming isochronal growth. See text for explanation. The egg hatching time has been corrected by using data in Marshall \& Orr (1972; their Table II)

\begin{tabular}{|lcccc|}
\hline Development & \multicolumn{2}{c}{$\begin{array}{c}\text { Balsfjorden } \\
\text { 3 }\end{array}$} & $\begin{array}{c}\text { North Sea } \\
\text { (Thompson 1982) }\end{array}$ & $\begin{array}{c}\text { Scotian Shelf } \\
\text { (Corkett \& McLaren 1986) }\end{array}$ \\
\hline Hatching to CI & 1.0 & 1.0 & 1.0 & 1.0 \\
Hatching to CII & 1.27 & 1.25 & 1.28 & 1.25 \\
Hatching to CII & 1.54 & 1.44 & 1.58 & 1.53 \\
Hatching to CIV & 1.69 & 1.68 & 1.93 & 1.81 \\
Hatching to CV & - & 2.46 & 2.33 & 2.11 \\
\hline
\end{tabular}




\section{DISCUSSION}

In laboratory growth experiments with copepods from temperate or warm waters, the response of growth and developmental rates to different temperature and food conditions has usually been evaluated during the growth period from $\mathrm{CI}$ to adults (e.g. Harris \& Paffenhöer 1980). The developmental time of nauplii Calanus finmarchicus from coastal areas of northern Norway is in general accordance with results reported for the species from temperate regions (Marshall \& Orr 1972). The results obtained for copepodite stages grown at $6{ }^{\circ} \mathrm{C}$ fell within those ranges given for the species at temperatures around 6 to $8^{\circ} \mathrm{C}$ (Table 4).

Suboptimal food conditions have been shown to increase the developmental time among nauplii and copepodite stages of calanoid copepods (e.g. Vidal $1980 \mathrm{a}, \mathrm{b})$. The food concentrations at which maximum developmental rate was attained $(P C)$ for copepodite Stage III of Calanus pacificus was ca $130 \mu \mathrm{g} \mathrm{C} \mathrm{I}^{-1}$ when growing in temperatures from 8 to $15.5^{\circ} \mathrm{C}$ (Vidal $1980 \mathrm{~b}$ ). $P_{C}$ decreased with decreasing temperature and stage of development (size), which means that nauplii of C. finmarchicus should be considered to attain maximum developmental rate at food concentrations around 30 to $50 \mu \mathrm{g} \mathrm{Cl}^{-1}$. These low food levels were unlikely to prevail either in the present experiments or in the natural environment in fjord areas around Tromsø during the annual recruitment period (Tables 1 and 3). The present data from developmental and mortality rates of $C$. finmarchicus should therefore not be considered as a result of suboptimal growth conditions.

If copepod development is equiproportional, as suggested by Corkett (1984), Corkett et al. (1986) and McLaren (1986), then it should be expected that the observed relative times to reach various copepodite stages should be the same at different temperatures, when calculated from the relative developmental rate of nauplii growth period. The copepodite stages of Calanus finmarchicus from northern Norway may have a different temperature response to the naupliar stages, since the relative time to reach the various copepodite stages is longer at $3^{\circ} \mathrm{C}$ than at $6{ }^{\circ} \mathrm{C}$. A certain amount of variability is inherent in rearing experiments, but the variation in relative developmental rate as found in $C$. finmarchicus from northern Norway, North Sea, and Nova Scotian waters could as well be indicative of differenct ecotypes among this species (see also Matthews 1966).

The effect of temperature on development has been found not to be constant throughout naupliar and copepodite stages for copepods from temperate waters. Studies on Pseudocalanus elongatus and Calanus sp. (Thompson 1982) and Calanus pacificus (Vidal 1980a) suggest that the rate of change from one stage to another becomes slower in the older, larger stages. This could also probably be seen in stage duration (Table 5) among copepodites from temperate and boreal regions grown at 5 to $8^{\circ} \mathrm{C}$. The use of the concept of equiproportional development to predict developmental time up to adults should be carefully considered in relation to diapause or arrested development in preadult stages of natural copepod populations, as for instance in arctic-boreal areas (Tande 1982, Tande et al. 1985). Arrested development may be even more evident in the Arctic species Calanus glacialis which is considered to have a generation cycle lasting 2 $y \mathrm{r}$ in the Arctic waters of the Barents Sea (Prygunkova 1968, Jaschnov 1972, Tande et al. 1985). Similar events may also occur during the life cycle of Calanus hyper-

Table 5. Calanus finmarchicus and C. helgolandicus. Stage duration (d) estimated in laboratory experiments and calculated from field investigations

\begin{tabular}{|c|c|c|c|c|c|c|c|c|}
\hline \multirow[t]{2}{*}{ Species } & \multirow[t]{2}{*}{ Region } & \multicolumn{5}{|c|}{ Stage duration } & \multirow{2}{*}{$\begin{array}{c}\text { Temperature } \\
\left({ }^{\circ} \mathrm{C}\right)\end{array}$} & \multirow[t]{2}{*}{ Source } \\
\hline & & $\mathrm{CI}$ & CII & CIII & CIV & $\mathrm{CV}$ & & \\
\hline \multirow{3}{*}{$\begin{array}{l}\text { C. finmarchicus/ } \\
\text { helgolandicus }\end{array}$} & Clyde Sea, UK & $3-5$ & $2-4$ & $3-11$ & $3-13$ & $4-19$ & $14-15$ & Marshall \& Orr 1955 \\
\hline & North Sea & 6.8 & 5.4 & 6.4 & 7.6 & 9.6 & 7.6 & Thompson 1982 \\
\hline & North Sea ${ }^{\mathrm{d} .} \mathrm{b}$ & 2 & 3 & $3-5$ & $4-5$ & $2-5$ & 6.2 & Williams \& Lindley 1980 \\
\hline \multirow[t]{10}{*}{ C. finmarchicus } & Firth of Clyde, UK & - & 16 & 18 & - & - & 0 & Matthews 1966 \\
\hline & & - & 8.4 & 10.5 & 11.8 & 1.6 .7 & 5 & \\
\hline & & - & 4.0 & 8.5 & 8.0 & 10.0 & 10 & \\
\hline & & - & 4.0 & 8.2 & 8.9 & 9.3 & 15 & \\
\hline & Nova Scotıa, Canada & - & 4 & 5 & 7 & 5 & 8.2 & Corkett et al. 1986 \\
\hline & Nova Scotia, Canada & - & - & 5 & 5.5 & 11 & 7 & Runge et al. 1985 \\
\hline & Western Norway ${ }^{a}$ & 2 & 4 & 6 & 13 & 250 & $4-6$ & Aksnes \& Magnussen 1983 \\
\hline & Western Norway ${ }^{\circ}$ & - & - & $2-9$ & $5-12$ & $12-13$ & Spring & Matthews at al. 1978 \\
\hline & & - & - & $8-10$ & $1-11$ & $61-159$ & Summer & \\
\hline & Northern Norway & 2.4 & 4.6 & 5.8 & 19 & - & 6 & Present study \\
\hline
\end{tabular}


boreus which has likewise been postulated by Grainger (1959) to have a 2 yr life cycle in the Arctic Ocean.

The usual procedure in growth studies under controlled conditions has been to cultivate nauplii at one temperature level, and then to separate the copepodites into groups for ongrowing at a range of temperatures spanning that experienced by the species under natural environmental conditions. In this manner, Cl's of various calanoid species have been introduced to temperature regimes 3 to $5^{\circ} \mathrm{C}$ above or below the temperature experienced during the nauplii growth period. In Calanus finmarchicus from the fjord areas around Tromsø, this cultivating procedure, in which $\mathrm{Cl}$ 's were transferred to a temperature of $0.5^{\circ} \mathrm{C}, 1.5^{\circ} \mathrm{C}$ below that experienced through the nauplii growth period, gave rise to high mortality. Furthermore mortality rates of populations experiencing a temperature increase of $1{ }^{\circ} \mathrm{C}$ appeared to be more variable than those experiencing a temperature increase of $4^{\circ} \mathrm{C}$ (Fig. 6).

Death from low sea temperatures is well known to occur and is particularly prevalent in habitats subject to thermal stress (reviewed in Kinne 1970). Experimental studies of Calanus spp. from regions other than northern Norway have also indicated high mortalities at low temperatures. By examining results presented by Thompson (1982) no estimates of developmental rates were obtained on copepodites of C. finmarchicus s. 1. reared at $4.5^{\circ} \mathrm{C}$ (her Table 6). From Corkett et al. (1986) it could be inferred that no development heyond copepodite Stage I was obtained at $2.5^{\circ} \mathrm{C}$ in $\mathrm{C}$. finmarchicus from Nova Scotian waters (their Fig. 2).

The temperature increase in boreal waters is a yearly predictable phenomenon during late spring and early summer (Table 2), which coincides with the annual recruitment period of Calanus finmarchicus. The temperature increase during this period is not abrupt but gradual. High mortalities among Cl, CII and CIII in C. finmarchicus in the present study could have been generated through abrupt temperature changes by transferring $\mathrm{CI}$ to different temperature regimes. However, the same effects were obtained in Calanus spp. from North Sea and Nova Scotian waters by maintaining the nauplii and copepodites stages at the same low temperature levels during the whole growth period (Thompson 1982, Corkett et al. 1986). This information has not until now been discussed in relation to either the prevailing experimental procedure for rearing copepods, nor to the potential ecological implications of arrested development or high mortalities among copepodite stages of $C$. finmarchicus and C. helgolandicus growing at low temperatures. On this basis it could be reasonable to formulate the hypothesis that during the annual recruitment period in spring, $C$. finmarchicus from arctic-boreal areas is not only sensitive to a temperature decrease, but also that a certain temperature increase is a prerequisite to successful growth from $\mathrm{Cl}$ to $\mathrm{CV}$.

In general, mortality rates are considered to be important in studies related to secondary production. but few estimates of mortality in natural populations of calanoid copepods have been published (see however Matthews et al. 1978, Aksnes \& Magnesen 1983, Myers \& Runge 1983). Landry (1983) suggested that the error in estimation of stage-specific mortality rates will be proportionate to the error in estimating the differences in duration between adjacent instars, and thereby influenced by the isochronal assumption. As the present results indicate, copepod species could be considered also to have age-specific physiological responses to low temperature which may generate temperaturedependent differential mortality among copepodite stages. A temperature-dependent mortality rate in natural populations of Calanus finmarchicus may not be a quantitative important factor in general. However, front regions, as for instance the Polar Front in the Barents Sea, are characterized by water masses with temperatures from -1 to $+2{ }^{\circ} \mathrm{C}$ covering extensive areas especially in eastern part of the Sea. These aspects should encourage further systematic evaluation of temperature-dependent mortality rates during the annual recruitment period of $C$. finmarchicus in arctic-boreal waters.

Acknowledgements. I thank M. Jobling and G.-A. Paffenhöfer for valuable comments on an earlier draft of this manuscript, and Jan Evjen and Elisabeth Graahl-Madsen for technical assistance during the experiments. This work was financially supported by the Norwegian Fisheries Research Council (NFFR), partially through the Norwegian Program for Marine Arctic Ecology (PRO MARE)

\section{LITERATURE CITED}

Aksnes, D. L., Magnesen, T (1983). Distribution, development, and production of Calanus finmarchicus (Gunnerus) in Lindåspollene, western Norway 1979. Sarsia 68: 195-208

Conover, R. J. (1967). Reproductive cycle, early development, and fecundity in laboratory populations of the copepod Calanus hyperboreus. Crustceana 13: 61-72

Corkett, C. J. (1972). Development rate of copepod eggs of the genus Calanus. J. exp. mar. Biol. Ecol. 10: 171-175

Corkett, C. J. (1984). Observations on development in copepods. Studies on Copepoda II. Proceedings of the First International Conference on Copepoda, Amsterdam, 1981. Crustaceana 7 : 150-153

Corkett, C. J., McLaren, I. A. (1970). Relationship between development rate of eggs and older stages of copepods. J mar, biol. Ass. U. K. 50: 161-168

Corkett, C. J., McLaren, I. A. (1978). The biology of Pseudocalanus. Adv. mar. Biol. 15: 1-231 
Corkett, C. J., McLaren, I. A., Sevigny, J.-M. (1986). The rearing of the marine calanoid copepods Calanus finmarchicus (Gunnerus). C. glacialis Jaschnov and C. hyperboreus Kroyer with comment on the equiproportional rule. In: Schriever, G., Schminke, H. K., Shih, C. T. (eds.) Proceedings of the 2 nd Int. Conference on Copepoda, Ottawa, Syllogeus No. 58, Ottawa, p. 539-546

Eilertsen, H. C., Taasen, J. P. (1984). Investigations on the plankton community of Balsfjorden, northern Norway: the phytoplankton 1976-1978. Environmental factors, dynamics of growth, and primary production. Sarsia 69 $1-15$

Frost, B. W. (1972). Effects on size and concentration of food particles on the feeding behaviour of the marine planktonic copepod Calanus pacificus. Limnol. Oceanogr 17. 805-815

Grainger, E. H. (1959). The annual oceanographic cycle at Igloolik in the Canadian Arctic. I. The zooplankton and physical and chemical observations. J. Fish. Res. Bd Can. 16: 453-501

Jaschnov, W. A. (1972). On the systematic status of Calanus glacialis, Calanus finmarchicus and Calanus helgolandicus. Crustaceana 22: 279-284

Kinne, O. (1970). Temperature. In: Kinne, O. (ed.) Marine ecology, Vol. I, Environmental factors, Part 1. John Wiley, London, p. $407-514$

Landry, M. R. (1983). The development of marine calanoid copepods with comment on the isochronal rule. Limnol. Oceanogr. 28: 614-624

Marshall, S. M., Orr, A. P. (1972). The biology of a marine copepod Calanus finmarchicus (Gunnerus). Oliver and Boyd, Edingburgh and London

Matthews, J. B. L. (19667. Experimental investigations of the systematic status of Calanus finmarchicus and C. glacialis (Crustacea: Copepoda). In: Barnes, H. (ed.) Some contemporary studies in marine science. Allen and Unwin, London, p. 479-492

Matthews, J. B. L., Hestad, L., Bakke, J. L. W. (1978). Ecological studies in Korsfjorden, western Norway. The generations and stocks of Calanus hyperboreus and C. finmarchicus in 1971-1974. Oceanologica Acta 1: 277-284

McLaren, I. A. (1978). Generation lengths of some temperate marine copepods: estimation, prediction and implications. J. Fish. Res. Bd Can. 35: 1330-1342

McLaren, I. A. (1986). Is 'structural' growth of Calanus potentially exponential? Limnol. Oceanogr. 31 (6): 1342-1346

McLaren, I. A., Corkett, C. J. (1986). Life cycles and production of two copepods on the Scotian Shelf, eastern Canada. In: Schriever, G., Schminke, H. K., Shih, C. T (eds.) Proceedings of the 2 nd Int. Conference on Copepoda, Ottawa, Syllogens No. 58, Ottawa, p. 362-368

McLaren, I. A., Corkett. C. J., Zillioux, E. J. (1969). Temperature adaptations of copepod eggs from the arctic to the trophics. Biol. Bull. mar biol. Lab., Woods Hole 137: 486-493

Miller, C. B., Johnson, J. K., Heinle, D. R. (1977). Growth rules in the marine copepod genus Acartia. Limnol. Oceanogr 22: $326-335$

Myers, R. A., Runge, J. A. (1983). Predictions of seasonal natural mortality rates in a copepod population using lifehistory theory. Mar Ecol. Prog. Ser. 11: 189-194

Paffenhöfer, G.-A., Harris, R. P. (1979). Laboratory culture of marine holozooplankton and its contribution to studies of marine planktonic food webs. Adv. mar. Biol. 16: 211-308

Prygunkova, R. V. (1968). The development cycle of Calanus glacialis in the White Sea. Dokl. Akad. Nauk. SSSR 182: $1447-1450$

Runge, J. A., McLaren, I. A., Corkett, C. J., Bohrer, R. N. Koslow, J. A. (1985). Moulting rates and cohort development of Calanus finmarchicus and C. glacialis in the sea off southwest Nova Scotia. Mar. Biol. 86: 241-246

Sokal, R. R., Rohlf, F. J. (1981). Biometry. Freeman, San Francisco

Tande, K. S. (1982). Ecological investigations of the zooplankton community of Balsfjorden, northern Norway: generation cycles, and variations in body weight and body content of carbon and nitrogen related to overwintering and reproduction in the copepod Calanus finmarchicus (Gunnerus). J. exp. mar. Biol. Ecol. 62: 159-164

Tande, K. S., Hassel, A., Slagstad, D. (1985). Gonad maturation and possible life cycle strategies in Calanus finmarchicus and Calanus glacialis in the northwestern part of the Barents Sea. In: Gray, J. S., Christiansen, M. E. (eds.) Marine biology of polar regions and effects of stress on marine organisms. Wiley, Chichester, p. 141-155

Thompson, B. M. (1982). Growth and development of Calanus elongatus and Calanus sp. in the laboratory. J. mar. biol. Ass. U. K. 62: 359-372

Uye, S. I. (1980). Development of neritic copepods Acartia clausi and A. steueri. II. Isochronal larval development at various temperatures. Bull. Plan. Soc. Japan 27: 11-18

Vidal, J. (1980a). Physioecology of zooplankton. I. Effects of phytoplankton concentration, temperature, and body size on the metabolic rate of Calanus pacifius sp. Mar. Biol. 56: $111-134$

Vidal, J. (1980b). Physioecology of zooplankton. II. Effects on phytoplankton concentration, temperature, and body size on the development and moulting rates of Calanus pacificus and Pseudocalanus sp. Mar Biol. 56: 135-146

Vidal, J. (1980c). Physioecology of zooplankton. III. Effects of phytoplankton concentration, temperature, body size on the metabolic rate of Calanus pacificus. Mar. Biol. 56: 195-202

Vidal, J. (1980d). Physioecology of zooplankton. IV. Effects of phytoplankton concentration, temperature, and body size on the net production efficiency of Calanus pacificus. Mar Biol. 56. 203-211 